\title{
Frequency of Polyps and Adenocarcinoma in Colon Interposition After Esophagectomy in Adulthood - A Systematic Review
}

\author{
MAXIMILIAN SOHN ${ }^{1}$, AYMAN AGHA ${ }^{1}$, STEPHANIE TRUM $^{1}$, CHRISTIAN MOSER $^{1}$, FELIX GUNDLING $^{2}$, \\ ALFRED HOCHREIN ${ }^{3}$, JOHANN PRATSCHKE $^{4}$, FELIX AIGNER ${ }^{4}$ and PAUL RITSCHL ${ }^{4}$ \\ ${ }^{1}$ Department of General-, Abdominal-, Endocrine- and Minimally Invasive Surgery, \\ Munich Clinic Bogenhausen, Munich, Germany; \\ ${ }^{2}$ Department of Gastroenterology, Hepatology and Gastroenterologic Oncology, \\ Munich Clinic Bogenhausen, Munich, Germany; \\ ${ }^{3}$ OCM Clinic Munich, Munich, Germany; \\ ${ }^{4}$ Charité - Universitätsmedizin Berlin, Chirurgische Klinik, \\ Campus Charité MittelCampus Virchow-Klinikum, Berlin, Germany
}

\begin{abstract}
Background/Aim: Colon interposition counts among the most common techniques for reconstruction after esophagectomy. Availability of data on metachronous mucosal pathologies is weak. The aim of this review was to identify all reports on the development of metachronous adenoma and adenocarcinoma in colon interposition after esophagectomy in adulthood. Materials and Methods: A comprehensive search was conducted in MEDLINE/PubMed, Science Direct, Cochrane Library, Bayerische Staatsbibliothek München. All studies reporting on patients who received colon interposition as substitute after esophagectomy in adulthood for benign and malignant reasons were included. Results: Five retrospective studies were included, reporting on 1016 patients. Therein, no interval lesion was identified. One further study, which formally must be excluded for a misfit to inclusion criteria reports on three interval carcinomas within 365 patients. Because these lesions were the only ones found within a cohort analysis, results were supplementary reported in this review. Additionally, 31 case reports including 32 patients with benign $(n=7)$ or
\end{abstract}

This article is freely accessible online.

Correspondence to: Dr. Maximilian Sohn, Klinik für Allgemein-, Viszeral-Endokrine- und Minimalinvasive Chirurgie, Klinikum Bogenhausen, Städtisches Klinikum München $\mathrm{GmbH}$, Englschalkinger Strasse 77, 81925 Munich, Germany. Tel: +49 8992702756, e-mail: maximilian.sohn@klinikum-muenchen.de

Key Words: Colon interposition, esophagectomy, carcinoma, adenoma, review. malignant $(n=25)$ findings were analyzed. Median age was 63.5 years (interval carcinoma) and 69 years (benign lesion). Benign and malignant lesions were diagnosed after a median of 8.5 years. Conclusion: Due to the rareness of respective cohort studies, the frequency of metachronous lesions cannot be calculated accurately. The estimated rate of interval carcinoma is $0-0.22 \%$. Life-long endoscopic surveillance of patients with colon interposition is recommended.

Esophagectomy with replacement by colon interposition was first described by Kelling and Vuillet in 1911 (1, 2). Since then, the colon developed into the most commonly used esophageal substitute if the stomach is not available for reconstruction (3). The majority of patients undergoing esophagectomy with colon interposition for malignant disease are older than 55 years and thereby at risk for the development of colonic polyps. Further, patients with adenocarcinoma of the esophagus showed a significantly higher risk for the occurrence of colonic polyps (4). Patients, who receive the interposition procedure for benign pathologies are relevantly younger in common, therefore their lifetime risk for the development of mucosal changes in the substitute is relatively higher. To date, no systematic review focuses on the rate of mucosal changes such as adenoma and adenocarcinoma in colon interposition in adulthood.

This review was performed to identify available evidence on the development of metachronous adenoma and adenocarcinoma in colon interposition after esophagectomy for benign (e.g. Boerhaave-Syndrom, trauma, corrosive injury) and malignant reasons (esophageal cancer) in adulthood. 


\section{Materials and Methods}

Protocol and registration. The systematic review is based on a review protocol, designed in accordance to the PRISMA-PStatement (5-7).

The protocol is registered with the PROSPERO International Prospective Register of Systematic Reviews as CRD42017082144.

Eligibility criteria. All studies (randomized, non-randomized, case series, case reports), reporting on patients who received colon interposition after esophagectomy for benign (e.g. BoerhaaveSyndrom, trauma, caustic injury) and malignant reasons (adenocarcinoma or squamous cell carcinoma of the esophagus) were eligible for data analysis. The search was not limited to a certain time frame. Studies had to be fully published, available as full text and written in English or German language.

Exclusion criteria. Exclusion from the analysis: colon interposition in children, abstract/full-text was not available, not in English or German language, review articles.

Information sources and search strategy. A bibliographic search was conducted in Medline/PubMed, Science Direct, Cochrane database and Bayerische Staatsbibliothek from 12-1-2017 to 4-1-2018. In two cases, authors were contacted for full text transfer. In 13 cases of older full-text articles, not available in one of the abovementioned databases, full-text articles were directly requested from editorial offices of the publishing journals. Combinations of the following terms were used: "polyp", "interposition", "colon" ("polyps"[MeSH Terms] OR "polyps"[All Fields] OR "polyp"[All Fields]) AND "interposition"[All Fields] AND ("colon"[MeSH Terms] OR "colon"[All Fields]). The PubMed similar articles function was used to extend potential hits. References of all eligible reports were screened for further information.

Study selection. Selection process. Three authors (SM, GF, PR) independently assessed titles and/or abstracts of all identified reports and excluded those considered irrelevant. Afterwards, full-text papers were screened on their accordance to inclusion criteria. One author (SM) extracted data from the included studies and a second (GF) checked extracted data. Disagreements were discussed and solved.

Data items. Data were extracted using the PICO-System $(8,9)$. The PICO tool focuses on the Population, Intervention, Comparison and Outcomes of scientific publications. It is used to identify components of clinical evidence within the literature. Additionally, the following items were extracted: first author, year of publication, study type, patient age, patient gender, underlying disease, intervention, main outcome measures, evidence of polyps and/or adenocarcinoma, interval between colon interposition and diagnosis of polyps/adenocarcinoma, evidence of colonic polyps/adenocarcinoma within preoperative colonoscopy, metastatic disease in case of carcinoma, therapy of polyps/adenocarcinoma prior to interposition, therapy of polyps/adenocarcinoma in interposition.

Risk of bias in individual studies. Risk of bias of non-randomized studies was assessed using the Newcastle-Ottawa Scale (NOS). NOS was designed as a quality assessment tool to evaluate both nonrandomized cohort and case control studies. The quality of assessed studies was evaluated, using a star rating system. The overall maximum score was nine stars. The following domains were included: selection of study groups (maximum score: four stars), comparability of study groups (maximum score: two stars), ascertainment of exposures (for case control studies) or outcome of interest (for cohort studies) (maximum score: 3 stars) (10) (Table I).

Synthesis of results. A narrative synthesis of the results was performed since the number of cohort studies was too low for metaanalysis. Further, inclusion criteria as well as follow-up workflow and follow-up examinations were inhomogeneous.

\section{Results}

Study selection. Overall, 157 studies were screened for eligibility. Thereof, 72 records remained after exclusion of duplicates. After screening and full-text assessment, 37 records remained (case reports: $n=31$; non-randomized cohort studies: $n=6$ ). No randomized trials were identified according to the inclusion criteria. Six studies were excluded within the screening process and 29 more after full-text assessment (Figure 1, Table II).

Characteristics of cohort studies. Detailed study characteristics are depicted in Tables III and IV.

Study 1. In 1982, Akiyama and coworkers published data from a questionnaire-based national survey (9). Therein, 223 members of the Japanese society for Esophageal Diseases were asked to report on interval carcinoma within the substitute after esophagectomy. In 9.5\% ( $\mathrm{n}=617)$, colonic interposition was applied for intestinal reconstruction. In these cases, no carcinoma occurred. The authors did not indicate the time frame in which the abovementioned operations were performed. Moreover, it is not clearly described whether all patients were followed up consequently or if only symptomatic patients received further diagnostic work up (11).

Study 2. Eleftheriadis reported on a series of 13 patients who received colonic interposition after esophagectomy for benign disease from 1967 to 1983. Eight of them were available for endoscopic follow up, applied within an average time of 7.2 years after initial surgery. While endoscopic examination did not render relevant evidence of colitis, histologic samples of all but one patient showed microscopic changes: inflammation $(n=6)$ and fibrosis $(n=1)$. No cases of malignancy or pre-malignant adenoma were found (12).

Studies $3+4$. Two studies by Isolauri et al. focused on both an isolated cohort of patients who received colon interposition for benign disease (Timeframe: 1964-1985) and a mixed cohort of patients with underlying malignant and benign pathologies (Timeframe: 1964-1985). According to the period of patient inclusion, the benign cohorts in both 


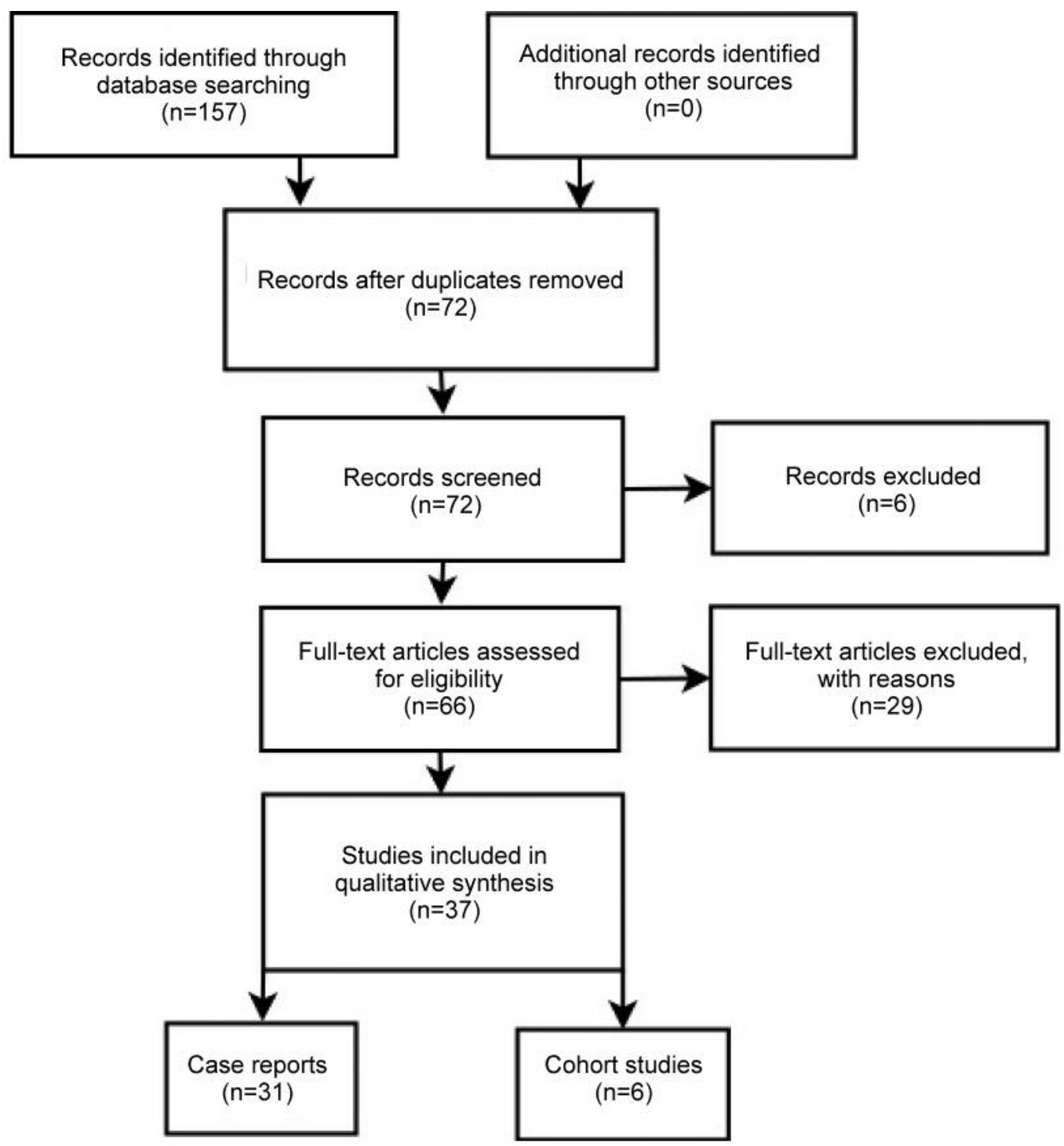

Figure 1. PRISMA flow sheet.

studies seem to be the same. Therefore, a certain overlap must be assumed within the results. Retrospectively, it is not possible to explain slight differences between both cohorts All patients available for follow up underwent endoscopic examination of the interposition. Therein, the mucosa was evaluated macroscopically. Moreover, bacterial and fungal specimens were obtained. Overall, no graft-malignancies were found after a median follow up of 57 months, respectively 67 months in both studies. However, within the 1991 analysis, one carcinoma was found, classified as "recurrent carcinoma" and not as malignancy, originating from the interposition. Since no histopathologic analysis was available, this carcinoma could not be clearly assigned to the organ it originated from $(13,14)$.
Study 5. In 1996, Pompeo et al. published data on 100 consecutive patients having received esophagocoloplasty (13). Patients were divided into three groups: group A: congenital disease $(n=22)$, group $B$ : acquired benign lesions $(n=36)$, group $C$ : malignant disease $(n=42)$. Out of the 42 patients belonging to group $\mathrm{C}$ only 5 survived more than 5 years. These patients were excluded from the analysis by the authors. Moreover, all patients with follow-up examinations of less than one year and two cases of late deaths were excluded $(n=7)$. Thus, data from the 51 remaining patients were reviewed. A subdivision into pediatric $(n=25)$ and adult $(n=26)$ patients was made. The follow up rate was $100 \%$. Due to inclusion criteria of the presented study, only information on adult patients was included into the analysis. Within the 
Table I. Newcastle-Ottawa Scale for assessing the quality of nonrandomized studies.

\begin{tabular}{|c|c|c|c|c|c|c|c|c|c|c|}
\hline \multirow[b]{2}{*}{ Author } & \multirow[b]{2}{*}{ Year } & \multicolumn{4}{|c|}{ Selection } & \multirow{2}{*}{$\frac{\text { Comparability }}{5}$} & \multicolumn{4}{|c|}{ Outcome assessment } \\
\hline & & 1 & 2 & 3 & 4 & & 6 & 7 & 8 & Score (max 9 Stars) \\
\hline Akiyama & 1982 & $*$ & $*$ & $*$ & $*$ & $* *$ & - & - & - & 6 \\
\hline Eleftheriadis E & 1987 & $*$ & - & $*$ & $*$ & - & $*$ & - & $*$ & 5 \\
\hline Isolauri & 1988 & $*$ & - & $*$ & $*$ & - & $*$ & $*$ & $*$ & 6 \\
\hline Isolauri & 1991 & $*$ & - & $*$ & $*$ & - & $*$ & $*$ & $*$ & 6 \\
\hline Pompeo & 1996 & $*$ & - & $*$ & $*$ & - & $*$ & $*$ & $*$ & 6 \\
\hline Jeysingham & 1999 & $*$ & - & $*$ & $*$ & - & $*$ & $*$ & $*$ & 6 \\
\hline
\end{tabular}

Table II. Excluded studies with reasons for exclusion.

\begin{tabular}{|c|c|c|}
\hline Author & Year & Reason for exclusion \\
\hline Jayes P & 1957 & Carcinoma in a skin tube reconstruction \\
\hline Hanna EA & 1967 & $\begin{array}{l}\text { Analysis of postoperative function, no endoscopic follow-up, no information on primary or } \\
\text { secondary outcome parameters }\end{array}$ \\
\hline Mullen DC & 1970 & No structured follow-up, no endoscopic follow-up, no information on primary or secondary outcome \\
\hline Stephens H & 1971 & No endoscopic follow-up \\
\hline Harvey JG & 1979 & $\begin{array}{l}\text { Report on postoperative fibrosis of the interposition, no information on primary or } \\
\text { secondary outcome parameters }\end{array}$ \\
\hline Wilkins EW & 1980 & No endoscopic follow-up, no information on primary or secondary outcome parameters \\
\hline Hankins JR & 1984 & $\begin{array}{l}\text { Analysis of postoperative function, no endoscopic follow-up, no information on primary or } \\
\text { secondary outcome parameters inclusion of adults and children }\end{array}$ \\
\hline Larson TC 3rd & 1985 & No endoscopic follow-up, no information on primary or secondary outcome parameters \\
\hline Wetstein L & 1988 & Letter to the editor, no original case report \\
\hline Paris F & 1991 & $\begin{array}{l}\text { No structured endoscopic follow-up, no information on primary or secondary outcome parameters, } \\
\text { follow-up on postoperative function }\end{array}$ \\
\hline Theile & 1991 & Double publication of one single case \\
\hline Lindahl $\mathrm{H}$ & 1992 & Follow-up of interposition in children \\
\hline Cerfolio RJ & 1995 & No structured endoscopic follow-up, no information on primary or secondary outcome parameters \\
\hline Mansour KA & 1997 & No endoscopic follow-up, no information on primary or secondary outcome parameters \\
\hline Del Rosario MA & 1998 & Colon interposition in children \\
\hline Jung & 1999 & Esophageal Cancer \\
\hline Fürst H & 2001 & No follow-up, no information on primary or secondary outcome parameters \\
\hline Kotsis L & 2002 & No structured endoscopic follow-up, no information on mucosal changes within the cohort \\
\hline Popovici Z & 2003 & $\begin{array}{l}\text { No structured endoscopic follow-up, no information on primary or secondary outcome parameters, } \\
\text { follow-up postoperative function }\end{array}$ \\
\hline Novotny AR & 2005 & Adenocarcinoma in a skin tube reconstruction \\
\hline Martín MA & 2005 & Not written in English \\
\hline Hwang HJ & 2007 & Double publication of a single case in two journals \\
\hline Knezevic JD & 2007 & $\begin{array}{l}\text { No structured endoscopic follow-up, no information on primary or secondary outcome parameters, long term } \\
\text { follow-up focusing pattern of swallowing an eating, weight gain, presence of aspiration, quality of life }\end{array}$ \\
\hline Beaton MD & 2008 & Rectal cancer in FAP, no carcinoma in colonic interposition \\
\hline Dhir & 2008 & Report on patients with colonic interposition in the neonate period \\
\hline Chirica M & 2010 & No mucosal changes within the cohort, endoscopic follow-up on a symptom-based indication \\
\hline Klink & 2010 & No structured endoscopic follow-up, no information on primary or secondary outcome parameters \\
\hline Elshafei $\mathrm{H}$ & 2012 & Colon interposition in children \\
\hline Yeo MS & 2016 & Letter to the Editor, no original data on the disease \\
\hline
\end{tabular}

endoscopic follow up, no cases of interval carcinoma in the interposition were found. Since a differentiation between group $\mathrm{A}$ and $\mathrm{B}$ was not given in regard to benign interval lesions, those were not included in the review (15).
Jeyasingham et al. (14) reported on two cases $(0.6 \%)$ of adenocarcinoma at the cologastric junction and one case of adenocarcinoma of the interposed colon (0.3\%) within a cohort of 365 patients who survived hospital stay after 
Table III. PICOS question for cohort studies.

\begin{tabular}{|c|c|c|c|c|c|c|}
\hline \multirow[t]{2}{*}{ Author } & \multicolumn{6}{|c|}{ PICOS } \\
\hline & $\begin{array}{c}\text { Patient/ } \\
\text { Population }\end{array}$ & Intervention & Comparison & Outcomes & $\begin{array}{l}\text { Study } \\
\text { design }\end{array}$ & $\begin{array}{l}\text { Median } \\
\text { Follow-up } \\
\text { (month) }\end{array}$ \\
\hline $\begin{array}{l}\text { Akiyama } \\
(1982)\end{array}$ & $\begin{array}{l}\text { Adult patients after } \\
\text { esophagectomy for benign } \\
\text { and malignant disease }\end{array}$ & $\begin{array}{l}\text { Esophageal } \\
\text { replacement } \\
\text { by colon }\end{array}$ & $\begin{array}{l}\text { Esophageal } \\
\text { replacement by } \\
\text { stomach, skin or other }\end{array}$ & $\begin{array}{l}\text { Interval carcinoma } \\
\text { in the esophageal } \\
\text { replacement }\end{array}$ & $\begin{array}{c}\text { Retrospective, } \\
\text { questionnaire-based } \\
\text { survey }\end{array}$ & Not mentioned \\
\hline $\begin{array}{l}\text { Eleftheriadis } \\
\text { (1987) }\end{array}$ & $\begin{array}{l}\text { Adult patients after } \\
\text { esophagectomy for } \\
\text { benign disease }\end{array}$ & $\begin{array}{l}\text { Replacement } \\
\text { Replacement } \\
\text { by colon }\end{array}$ & None & $\begin{array}{l}\text { Mucosal changes in } \\
\text { interposed colon } \\
\text { by endoscopy }\end{array}$ & $\begin{array}{l}\text { Retrospective } \\
\text { (Follow-up: } \\
\text { prospective) }\end{array}$ & $86.4(12-156)$ \\
\hline $\begin{array}{l}\text { Isolauri J } \\
\text { (1988) }\end{array}$ & $\begin{array}{l}\text { Adult patients after } \\
\text { esophagectomy for } \\
\text { benign disease }\end{array}$ & $\begin{array}{l}\text { Esophageal } \\
\text { replacement } \\
\text { by colon }\end{array}$ & None & $\begin{array}{l}\text { Mucosal changes in } \\
\text { interposed colon } \\
\text { by endoscopy }\end{array}$ & $\begin{array}{l}\text { Retrospective } \\
\text { (Follow-up: } \\
\text { prospective) }\end{array}$ & $67(5-180)$ \\
\hline $\begin{array}{l}\text { Isolauri J } \\
(1991)\end{array}$ & $\begin{array}{l}\text { Adult patients after } \\
\text { esophagectomy for } \\
\text { benign and } \\
\text { malignant disease }\end{array}$ & $\begin{array}{l}\text { Esophageal } \\
\text { replacement } \\
\text { by colon }\end{array}$ & None & $\begin{array}{l}\text { Mucosal changes in } \\
\text { interposed colon } \\
\text { by endoscopy }\end{array}$ & $\begin{array}{l}\text { Retrospective } \\
\text { (Follow-up: } \\
\text { prospective) }\end{array}$ & $57(5-180)$ \\
\hline $\begin{array}{l}\text { Pompeo } \\
\text { (1996) }\end{array}$ & $\begin{array}{l}\text { Consecutive patients } \\
\text { after esophagectomy }\end{array}$ & $\begin{array}{l}\text { Esophageal } \\
\text { replacement } \\
\text { by colon }\end{array}$ & None & $\begin{array}{c}\text { Results after } \\
\text { esophagocoloplasty }\end{array}$ & Retrospective & $6.6(1-12)$ \\
\hline $\begin{array}{l}\text { Jeyasingham } \\
\text { (1999) }\end{array}$ & $\begin{array}{l}\text { Adult patients and } \\
\text { children who survived } \\
\text { immediate postoperative } \\
\text { hospital stay after } \\
\text { esophagectomy for } \\
\text { benign disease }\end{array}$ & $\begin{array}{l}\text { Esophageal } \\
\text { replacement } \\
\text { by colon }\end{array}$ & None & $\begin{array}{l}\text { Functional and } \\
\text { mechanical } \\
\text { problems after } \\
\text { esophageal } \\
\text { replacement by } \\
\text { colon interposition }\end{array}$ & Retrospective & $\begin{array}{c}(84-456) \\
\text { (median not } \\
\text { mentioned) }\end{array}$ \\
\hline
\end{tabular}

esophagectomy with colon interposition for benign reasons. The cohort consisted of pediatric and adult patients and was therefore formally excluded from the analysis, because allocation of respective cases to the adult or pediatric cohort was not completely comprehensible. Because the described interval carcinomas are the only ones reported in the context of a cohort study and not as single case reports or case series, we decided to report on the analysis even though it did not accurately fit our inclusion criteria (16).

Overall, five retrospective cohort studies by four authors were included in the analysis, reporting on 1016 patients. Therein, no case of an interval carcinoma or premalignant adenoma was diagnosed in the interposed colon. Adding results of Jeyasingham to the analysis, interval carcinoma would have been detected in $0.22 \%$ of analyzed patients

Risk of bias within studies. Per protocol, the risk of bias within retrospective studies was assessed, using the Newcastle-Ottawa scale (10). No study was rated with the highest possible score of 9 stars (Table I).

Characteristics of case reports. Overall, 31 case reports including 32 patients who developed benign or malignant interval pathologies within their colon interposition were identified (17-47). Baseline characteristics and findings of the specific lesions are depicted in Table V. Therein, reports on benign $(n=7)$ and malignant $(n=25)$ findings are presented separately. Median age was 63.5 years (range $=18-80$ years) in patients with interval carcinoma and 69 years (range $=60$ 73 years) in cases of benign lesions of the interposition. Carcinomas as well as benign lesions of the interposition were diagnosed after a median of 8.5 years $(7$ months to 55 years in cases of malignant findings, 1 to 16 years in cases of benign findings). Information on endoscopic findings of the colon before being used as interposition were only available in one report, showing an adenomatous polyp. Underlying disease leading to esophagectomy was malignant in $42.9 \%$ of cases with benign interval lesion and in $52 \%$ of reports on interval carcinoma.

\section{Discussion}

Esophageal replacement using the colon is one of the most common techniques of reconstruction after esophagectomy for both benign and malignant diseases. In general, the colon is proven to be a long lasting and well fit substitute, showing excellent postoperative function as well as alimentary satisfaction and quality of life $(3,48)$. However, 
Table IV. Characteristics of cohort studies.

\begin{tabular}{|c|c|c|c|c|c|c|c|}
\hline Author & $\begin{array}{l}\text { Benignant } \\
(\mathrm{n})\end{array}$ & $\underset{(\mathrm{n})}{\text { Malignant }}$ & $\begin{array}{l}\text { Finding at } \\
\text { follow-up } \\
\text { examination }\end{array}$ & $\begin{array}{l}\text { Interval } \\
\text { carcinoma } \\
\text { (n) }\end{array}$ & $\begin{array}{l}\text { Follow-up, } \\
\text { n (\%) }\end{array}$ & $\begin{array}{l}\text { Time to interval } \\
\text { adenoma/ } \\
\text { carcinoma }\end{array}$ & $\begin{array}{c}\text { Results after } \\
\text { therapy of } \\
\text { interval pathology }\end{array}$ \\
\hline Akiyama (1982) & 35 & 582 & - & 0 & Not indicated & - & - \\
\hline $\begin{array}{l}\text { Eleftheriadis } \\
\text { (1987) }\end{array}$ & 13 & 0 & $\begin{array}{l}\text { Microscopic inflammation } \\
\quad(\mathrm{n}=6) \text {; fibrosis }(\mathrm{n}=1)\end{array}$ & 0 & $8(61.5)$ & - & - \\
\hline $\begin{array}{l}\text { Isolauri } \\
(1988)\end{array}$ & 60 & 0 & $\begin{array}{l}\text { Macroscopic colitis }(n=6) \text {; } \\
\text { inflammatory polyp }(n=1) \text {, } \\
\text { evidence of candida }(n=23)\end{array}$ & 0 & $41(68.3)$ & - & - \\
\hline $\begin{array}{l}\text { Isolauri } \\
(1991)\end{array}$ & 60 & 248 & $\begin{array}{l}\text { Macroscopic inflammation } \\
(\mathrm{n}=5) \text {; hyperanemia } \\
\text { and friability }(\mathrm{n}=2)\end{array}$ & 0 & $36(11.7)$ & Not mentioned & Not mentioned \\
\hline $\begin{array}{l}\text { Pompeo } \\
\text { (1996) }\end{array}$ & $\begin{array}{l}\text { Acquired: } n=36 ; \\
\text { congenital: } n=22\end{array}$ & 42 & $\begin{array}{c}\text { Proximal anastomosis } \\
\text { stenosis }(\mathrm{n}=18), \\
\text { Distal anastomosis } \\
\text { stenosis }(\mathrm{n}=1), \\
\text { Esophagitis }(\mathrm{n}=1), \\
\text { Stasis due to } \\
\text { redundancy }(\mathrm{n}=5), \\
\text { Stasis due to } \\
\text { pylorospasm }(\mathrm{n}=1), \\
\text { Peptic colitis }(\mathrm{n}=2), \\
\text { Anastomotic ulcus }(\mathrm{n}=1)\end{array}$ & 0 & $51 \%$ & - & - \\
\hline $\begin{array}{l}\text { Jeyasingham } \\
\text { (1999) }\end{array}$ & 365 & - & $\begin{array}{l}\text { Colo-bronchial fistula }(\mathrm{n}=2) \text {, } \\
\text { Colo-cutaneous fistula }(\mathrm{n}=2) \text {, } \\
\text { Diaphragmatic herniation }(\mathrm{n}=3) \text {, } \\
\text { Pseudodiverticulosis }(\mathrm{n}=2) \text {, } \\
\text { Redundancy of the colonic } \\
\text { segment }(\mathrm{n}=17), \\
\text { Adenocarcinoma of the } \\
\text { cologastric junction }(\mathrm{n}=2) ; \\
\text { Adenocarcinoma of the } \\
\text { interposed colon }(\mathrm{n}=1)\end{array}$ & , & $100 \%$ & $\begin{array}{l}\text { Carcinoma of } \\
\text { the cologastric } \\
\text { junction: } \\
14 \text { and } 17 \text { years } \\
\text { No information } \\
\text { on the case of } \\
\text { adenocarcinoma of } \\
\text { the interposition }\end{array}$ & Not mentioned \\
\hline
\end{tabular}

apart from functional issues, mucosal pathologies of the interposition have been described but are yet to be systematically assessed. Therefore, we performed the presented systematic review.

According to data extracted from the included cohort studies, the risk of interval lesions was found to be extremely low. With inclusion criteria applied strictly, a rate of $0 \%$ can be calculated from a cohort of 1016 patients. Beyond this, 7 case reports present data on benign interval lesions and 25 report on interval carcinoma in the esophageal substitute. In this context, a certain risk of mucosal changes must be estimated. Characteristics given by the analyzed case reports are all limited to the index case. Information on the total cohort of esophagectomies with consecutive interposition of the colon from the respective institution is lacking. Since the overall number of operations is not known, calculation of the occurrence risk of metachronous lesions is not possible. According to the presented data, the development of mucosal changes takes several years, showing a median of 8.5 years after index operation. A potential rearrangement of the mucosal microbiota following the positional change of the colon, with respective alteration of mucosal resistance may be assumed. Yet, no experimental studies report on this thesis. However, the interposed colon is exposed to an altered dietary composition as well as to potential gastric and biliary reflux in the distal part of the substitute. These aspects potentially facilitate the additional development of mucosal changes $(14,49)$. Improved diagnostic techniques as well as the improvement of perioperative (neoadjuvant and adjuvant) therapies lead to earlier detection and a significantly higher rate of long-term survival in patients suffering from esophageal cancer (37). Moreover, patients operated for benign disease have no relevant limitations of their life expectancy in case of survival of the acute postoperative phase and adequate anastomotic healing. Consecutively, a theoretical risk of mucosal interval pathologies exists in both groups. Moreover, evidence was found, that patients, suffering from esophageal cancer are at 
Table V. Case reports.

\begin{tabular}{|c|c|c|c|c|c|c|c|c|c|c|}
\hline Author & Year & Age & Gender & $\begin{array}{l}\text { Underlying } \\
\text { disease }\end{array}$ & $\begin{array}{c}\text { Initial } \\
\text { operation }\end{array}$ & $\begin{array}{l}\text { Findings at } \\
\text { follow-up } \\
\text { endoscopy within } \\
\text { the interposition }\end{array}$ & Histology & $\begin{array}{l}\text { Time between } \\
\text { initial operation } \\
\text { and interval- } \\
\text { lesion (years) }\end{array}$ & $\begin{array}{c}\text { Eendoscopic } \\
\text { therapy }\end{array}$ & $\begin{array}{c}\text { c Surgical } \\
\text { therapy }\end{array}$ \\
\hline \multicolumn{11}{|c|}{ Benign interval lesion } \\
\hline Szántó (17) & 1981 & 65 & M & $\begin{array}{l}\text { Mechanic esophageal } \\
\text { stenosis after } \\
\text { tube insertion }\end{array}$ & $\mathrm{PE}$ & $\begin{array}{c}5 \mathrm{~mm} \text { polyp } \\
(6 \mathrm{~cm} \text { aboral of } \\
\text { the anastomosis })\end{array}$ & Adenoma & 1 & EMR & No \\
\hline Kovacs (18) & 1997 & 66 & M & $\begin{array}{c}\text { Inflammatory } \\
\text { Recurrent esophageal } \\
\text { stricture }\end{array}$ & $\mathrm{PE}$ & $\begin{array}{l}\text { Two sessil } \\
\text { polyps }\end{array}$ & $\begin{array}{l}\text { TA without } \\
\text { dysplasia }\end{array}$ & 13 & EMR & No \\
\hline Altomare (19) & 2006 & 64 & M & ACE & $\mathrm{PE}$ & $\begin{array}{l}6 \mathrm{~mm} \text { polyp } 3 \mathrm{~cm} \\
\text { proximal to the } \\
\text { colonic-gastric } \\
\text { anastomosis }\end{array}$ & $\mathrm{TA}$ & 2 & $\begin{array}{c}\text { EMR/ } \\
\text { Polypectomy }\end{array}$ & No \\
\hline Tanno (20) & 2010 & 73 & M & $\begin{array}{l}\text { Carcinoma of the } \\
\text { esophagus (no } \\
\text { information on } \\
\text { histopathology) }\end{array}$ & $\mathrm{TE}$ & $\begin{array}{c}\text { Laterally } \\
\text { spreading tumors }\end{array}$ & TA, HGIN & 16 & EMR & No \\
\hline Ramage (21) & 2012 & 63 & $\mathrm{~F}$ & $\begin{array}{l}\text { Iatrogenic perforation } \\
\text { after Fundoplicatio }\end{array}$ & $\mathrm{TE}$ & 2 polyps & TA, LGIN & UK & EMR & No \\
\hline Ramage (21) & 2012 & 65 & M & $\begin{array}{l}\text { Carcinoma of the } \\
\text { esophagus (no } \\
\text { information on } \\
\text { histopathology) }\end{array}$ & $\mathrm{TE}$ & $1 \mathrm{~cm}$ polyp & $\begin{array}{l}\text { Tubovillous } \\
\text { adenoma, } \\
\text { LGIN }\end{array}$ & UK & EMR & No \\
\hline $\mathrm{Ng}(22)$ & 2016 & 60 & M & $\begin{array}{c}\text { Extrahepatic } \\
\text { portal hypertension }\end{array}$ & $\mathrm{TE}$ & $\begin{array}{l}1 \text { polyp and } \\
\text { a mass }\end{array}$ & TA, LGIN & 13 & No & No \\
\hline \multicolumn{11}{|c|}{ Malignant interval lesion } \\
\hline Goldsmith (23) & 1968 & 51 & $\mathrm{~F}$ & $\begin{array}{l}\text { Epidermoid } \\
\text { carcinoma }\end{array}$ & TE & $\begin{array}{l}\text { Esophagram: } \\
5 \times 3 \mathrm{~cm} \text { filling } \\
\text { polypoid defect }\end{array}$ & $\mathrm{AC}$ & 2 & $\mathrm{re}$ & $\begin{array}{l}\text { Segmental } \\
\text { resection of the } \\
\text { interposition }\end{array}$ \\
\hline Licata (24) & 1978 & 40 & M & CI & TE & Friable mass & Colonic AC & 11 & No & No \\
\hline Haerr (25) & 1987 & 72 & M & SCC & $\mathrm{TE}$ & $\begin{array}{c}\text { Primary } \\
\text { adenocarcinoma } \\
\text { of the } \\
\text { interposed colon }\end{array}$ & $\mathrm{AC}$ & 9 & th & $\begin{array}{l}\text { No surgical } \\
\text { therapy due to } \\
\text { infiltration of } \\
\text { the sternum }\end{array}$ \\
\hline Houghton (26) & 1989 & 64 & M & $\begin{array}{l}\text { Benign } \\
\text { esophageal } \\
\text { stricture }\end{array}$ & $\mathrm{PE}$ & $\begin{array}{l}\text { Polypoid "neo- } \\
\text { esophageal" growth }\end{array}$ & $\mathrm{AC}$ & 20 & $\begin{array}{l}\mathrm{i} \\
\mathrm{i}\end{array}$ & $\begin{array}{l}\text { Resection } \\
\text { of the } \\
\text { interposition } \\
\text { with gastric } \\
\text { interposition }\end{array}$ \\
\hline $\begin{array}{l}\text { Theile } \\
\text { (27) }\end{array}$ & 1991 & 55 & M & $\begin{array}{l}\text { Adenocarcinoma } \\
\text { of the gastro- } \\
\text { esophageal junction }\end{array}$ & $\mathrm{TE}$ & $\begin{array}{l}\text { Colonic adeno- } \\
\text { carcinoma in } \\
\text { the interposition }\end{array}$ & $\mathrm{AC}$ & 13 & it & $\begin{array}{l}\text { Segmental } \\
\text { resection } \\
\text { of the } \\
\text { interposition, } \\
\text { colo-jejuno- } \\
\text { stomy }\end{array}$ \\
\hline Lee (28) & 1994 & 75 & $\mathrm{~F}$ & $\mathrm{SCC}$ & $\begin{array}{l}\text { Pharyngola- } \\
\text { rygectomy }\end{array}$ & $\begin{array}{l}\text { Tight structure } \\
\text { at the upper part } \\
\text { of the colonic } \\
\text { graft with a } \\
\text { luminal diameter } \\
\text { of } 1 \mathrm{~mm}\end{array}$ & $\mathrm{AC}$ & 20 & No & $\begin{array}{l}\text { Colonic } \\
\text { graft } \\
\text { resection }\end{array}$ \\
\hline
\end{tabular}


Table V. Continued

\begin{tabular}{|c|c|c|c|c|c|c|c|c|c|c|}
\hline Author & Year & Age & Gender & $\begin{array}{c}\text { Underlying } \\
\text { disease }\end{array}$ & $\begin{array}{c}\text { Initial } \\
\text { operation }\end{array}$ & $\begin{array}{c}\text { Findings at } \\
\text { follow-up } \\
\text { endoscopy within } \\
\text { the interposition }\end{array}$ & Histology & $\begin{array}{l}\text { Time between } \\
\text { initial operation } \\
\text { and interval- } \\
\text { lesion (years) }\end{array}$ & $\begin{array}{c}\text { Eendoscopic } \\
\text { therapy }\end{array}$ & $\begin{array}{l}\text { c Surgical } \\
\text { therapy }\end{array}$ \\
\hline Altorjay (29) & 1995 & 65 & M & $\begin{array}{c}\text { Grave } \\
\text { esophagitis }\end{array}$ & $\begin{array}{l}\text { Distal } \\
\text { esopha- } \\
\text { gectomy, } \\
\text { esophago- } \\
\text { colo- } \\
\text { gastrostomy }\end{array}$ & $\begin{array}{l}\text { Carcinoma } \\
\text { of the } \\
\text { interposed } \\
\text { colon }\end{array}$ & $\mathrm{AC}$ & 7 & re & $\begin{array}{l}\text { En bloc } \\
\text { resection } \\
\text { of the } \\
\text { interposition } \\
\text { with stomach } \\
\text { and spleen, } \\
\text { restoration by } \\
\text { Roux-en-y } \\
\text { esophago- } \\
\text { jejunostomy }\end{array}$ \\
\hline $\begin{array}{l}\text { Fritscher- } \\
\text { Ravens (30) }\end{array}$ & 1999 & 62 & $\mathrm{~F}$ & $\mathrm{SCC}$ & $\begin{array}{l}\text { Transhiatal } \\
\text { esopha- } \\
\text { gectomy }\end{array}$ & $\begin{array}{l}\text { 3-cm sized } \\
\text { proliferative } \\
\text { tumor with } \\
\text { induration and } \\
\text { infiltration } \\
\text { at the base }\end{array}$ & $\mathrm{AC}$ & 0.58 & EMR & $\begin{array}{l}\text { Segmental } \\
\text { resection } \\
\text { with end-to- } \\
\text { end anasto- } \\
\text { mosis } 6 \\
\text { weeks after } \\
\text { endoscopy }\end{array}$ \\
\hline Goyal (31) & 2000 & 78 & M & $\mathrm{AC}$ & $\begin{array}{l}\text { Distal esopha- } \\
\text { gectomy } \\
\text { and total } \\
\text { gastrectomy }\end{array}$ & 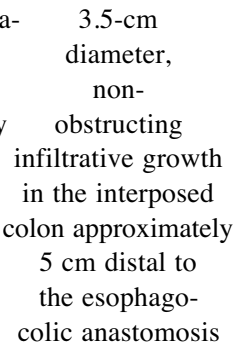 & $\begin{array}{c}\text { Colonic } \\
\text { AC }\end{array}$ & 10 & No & $\begin{array}{l}\text { Segmental } \\
\text { resection } \\
\text { of the } \\
\text { interposition }\end{array}$ \\
\hline Liau (32) & 2004 & 49 & M & $\begin{array}{l}\text { Carcinoma } \\
\text { of the esophagus } \\
\text { (no information } \\
\text { on histo- } \\
\text { pathology) }\end{array}$ & $\mathrm{TE}$ & $\begin{array}{l}\text { Ulcerative mass in } \\
\text { the colonic conduit }\end{array}$ & $\begin{array}{c}\text { Colonic } \\
\text { AC }\end{array}$ & 30 & No & No \\
\hline Hsieh (33) & 2005 & 18 & M & CI & PE & $\begin{array}{l}\text { Large erosional } \\
\text { lesion } 20 \mathrm{~cm} \\
\text { from the incisor }\end{array}$ & $\begin{array}{c}\text { Colonic } \\
\text { AC }\end{array}$ & 37 & $\begin{array}{l}\mathrm{i} \\
\mathrm{V}\end{array}$ & $\begin{array}{l}\text { Resection } \\
\text { of the } \\
\text { interposition } \\
\text { with cervical } \\
\text { esopha- } \\
\text { gostomy }\end{array}$ \\
\hline Hwang (34) & 2007 & 60 & $\mathrm{~F}$ & $\mathrm{CI}$ & TE & $\begin{array}{l}\text { Six polyps within } \\
\text { the colon inter- } \\
\text { position }(3-5 \mathrm{~mm})\end{array}$ & $\begin{array}{l}\text { Intra- } \\
\text { mucosal } \\
\text { AC }\end{array}$ & 40 & EMR & no \\
\hline Kuwabara (35) & 2008 & 68 & $\mathrm{~F}$ & $\begin{array}{l}\text { Adenocarcinoma } \\
\text { of the stomach }\end{array}$ & $\mathrm{TE}$ & $\begin{array}{l}\text { Mass arising at the } \\
\text { upper end of } \\
\text { the colonic graft }\end{array}$ & $\begin{array}{c}\text { Colonic } \\
\text { AC }\end{array}$ & 9 & No & $\begin{array}{l}\text { Segmental } \\
\text { resection } \\
\text { of the } \\
\text { interposition }\end{array}$ \\
\hline Lin (36) & 2008 & 74 & $\mathrm{~F}$ & $\begin{array}{l}\text { Carcinoma of the } \\
\text { esophagus (no } \\
\text { information on } \\
\text { histopathology) }\end{array}$ & $\begin{array}{l}\mathrm{I} \\
\mathrm{c} \\
\mathrm{r}\end{array}$ & $\begin{array}{l}\text { Irregular, ulcerative, } \\
\text { circumferential mass } \\
\text { located in the } \\
\text { lower part of } \\
\text { reconstruction colon }\end{array}$ & $\mathrm{AC}$ & 33 & No & $\begin{array}{l}\text { Segmental } \\
\text { resection } \\
\text { of the } \\
\text { interposition }\end{array}$ \\
\hline Bando (37) & 2010 & 80 & M & SCC & $\mathrm{TE}$ & $\begin{array}{l}\text { Laterally spreading } \\
\text { tumor of granular } \\
\text { type, } 20 \mathrm{~mm} \\
\text { diameter }\end{array}$ & $\begin{array}{l}\text { Intra- } \\
\text { mucosal } \\
\text { AC }\end{array}$ & 14 & ESD & No \\
\hline
\end{tabular}


Table V. Continued

\begin{tabular}{|c|c|c|c|c|c|c|c|c|c|c|}
\hline Author & Year & Age & Gender & $\begin{array}{l}\text { Underlying } \\
\text { disease }\end{array}$ & $\begin{array}{c}\text { Initial } \\
\text { operation }\end{array}$ & $\begin{array}{l}\text { Findings at } \\
\text { follow-up } \\
\text { endoscopy within } \\
\text { the interposition }\end{array}$ & Histology & $\begin{array}{l}\text { Time between } \\
\text { initial operation } \\
\text { and interval- } \\
\text { lesion (years) }\end{array}$ & $\begin{array}{l}\text { Eendoscopic } \\
\text { therapy }\end{array}$ & $\begin{array}{c}\text { ic } \begin{array}{c}\text { Surgical } \\
\text { therapy }\end{array}\end{array}$ \\
\hline Kia (38) & 2012 & 76 & M & $\mathrm{ACE}$ & $\begin{array}{l}2 \\
\mathrm{pr} \\
\mathrm{g} \\
\mathrm{a} \\
\mathrm{pc} \\
\text { th }\end{array}$ & $\begin{array}{l}2 \text { small polyps just } \\
\text { proximal to the colo- } \\
\text { gastric anastomosis+ } \\
\text { a larger } 4-\mathrm{cm} \text { sessile } \\
\text { polyp } 10-\mathrm{cm} \text { distal to } \\
\text { the upper esophageal } \\
\text { sphincter }\end{array}$ & $\begin{array}{l}- \\
+ \\
\text { o } \\
\text { o } \\
1\end{array}$ & 15 & EMR & No \\
\hline Shersher (39) & 2011 & 60 & M & $\begin{array}{l}\text { Benign esophageal } \\
\text { stricture }\end{array}$ & $\begin{array}{l}\text { of } \\
\text { fr }\end{array}$ & $\begin{array}{l}\text { Adenocarcinoma } \\
\text { obstructing } 40 \% \\
\text { of the graft lumen, } 25 \\
\text { rom the incisor teeth }\end{array}$ & $\begin{array}{l}5 \\
h\end{array}$ & 40 & $\begin{array}{r}\text { No } \mathrm{Re} \\
\mathrm{i} \\
\end{array}$ & $\begin{array}{l}\text { Resection of the } \\
\text { interposition, } \\
\text { Ivor-Lewis } \\
\text { esophago- } \\
\text { gastric } \\
\text { anastomosis }\end{array}$ \\
\hline Kim (40) & 2012 & 70 & $\mathrm{~F}$ & CI & e & $\begin{array}{l}\text { 3-cm ulcerative, } \\
\text { extruding mass with } \\
\text { friable mucosa, } \\
\text { no obstruction } \\
\text { in the mid portion } \\
\text { of the interposition }\end{array}$ & 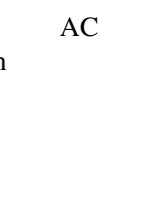 & 47 & No & No \\
\hline Spitali (41) & 2012 & 66 & M & $\mathrm{ACE}$ & $\begin{array}{c}\text { Total esopha- } \\
\text { gectomy }\end{array}$ & $\begin{array}{l}\text { - Circumferential } \\
\text { mass arising } \\
\text { from the colon }\end{array}$ & $\begin{array}{c}\text { Colonic } \\
\text { AC }\end{array}$ & 2 & $\begin{array}{r}\text { No } \quad \mathrm{Re} \\
\\
\text { il } \\
\\
\text { i }\end{array}$ & $\begin{array}{l}\text { Resection of the } \\
\text { ileocecal part } \\
\text { of the } \\
\text { interposition }\end{array}$ \\
\hline Sikorszki (42) & 2012 & 75 & F & CI & $\begin{array}{l}\text { Bypass of the } \\
\text { stenotic eso- } \\
\text { phagus in two } \\
\text { sessions using } \\
\text { the ileocolon } \\
\text { presternally a } \\
\text { ugmented by } \\
\text { a skin tube }\end{array}$ & $\begin{array}{lc}\text { e } & \text { No endoscopic } \\
- & \text { finding; } \\
\text { o } & \text { exulcerating } \\
\text { g } & \text { lesion in } \\
\text { n } & \text { the collar } \\
\text { a } & \text { region } \\
\text { y } & \end{array}$ & $\begin{array}{l}\text { Colonic } \\
\text { AC }\end{array}$ & 44 & No & $\begin{array}{l}\text { Segmental } \\
\text { resection } \\
\text { of the } \\
\text { interposition }\end{array}$ \\
\hline Aryal (43) & 2013 & 60 & M & CI & PE & $\begin{array}{l}4 \times 3-\mathrm{cm} \\
\text { ulcerated mass } \\
\text { in the colonic } \\
\text { esophagus }\end{array}$ & $\begin{array}{c}\text { Colonic } \\
\text { AC }\end{array}$ & 30 & No & No \\
\hline Grunner (44) & 2013 & 59 & $\mathrm{~F}$ & $\begin{array}{l}\text { Anastomotic } \\
\text { stricture after } \\
\text { proximal gastre- } \\
\text { ctomy for ulcer }\end{array}$ & PE & $\begin{array}{l}\text { Ulcerated lesion } \\
\text { obstructing } \\
\text { the distal } \\
\text { interposed colon }\end{array}$ & $\begin{array}{c}\text { Colonic } \\
\text { AC }\end{array}$ & 55 & No & $\begin{array}{l}\text { Segmental } \\
\text { resection } \\
\text { of the } \\
\text { interposition }\end{array}$ \\
\hline Tranchart (45) & 2014 & 66 & M & CI & $\mathrm{TE}$ & $\begin{array}{l}\text { 3-cm non- } \\
\text { obstructive } \\
\text { tumor in the colon } \\
\text { interposition }\end{array}$ & $\begin{array}{c}\text { Colonic } \\
\text { AC }\end{array}$ & 19 & No & No \\
\hline Cheng (46) & 2015 & 40 & F & CI & PE & $\begin{array}{l}\text { Esophageal tumor } \\
\text { in the colonic } \\
\text { interposition } \\
27 \mathrm{~cm} \text { from } \\
\text { the incisors }\end{array}$ & $\begin{array}{c}\text { Colonic } \\
\text { AC }\end{array}$ & 15 & No & No \\
\hline Kröner (47) & 2015 & 67 & M & ACE & $\mathrm{TE}$ & $\begin{array}{l}8 \times 5-\mathrm{cm} \text { mass at } \\
\text { the colonic } \\
\text { interposition } \\
\text { with partial } \\
\text { occlusion } \\
\end{array}$ & $\begin{array}{l}\text { No } \\
\text { information on } \\
\text { histological } \\
\text { findings, } \\
\text { macroscopical } \\
\text { characteristics } \\
\text { of malignancy }\end{array}$ & & $2 \times$ SEMS & No \\
\hline
\end{tabular}

SCC: Squamous cell carcinoma; ACE: adenocarcinoma of the esophagus; AEG: adenocarcinoma of the esophago-gastric junction; CI: caustic injury; TE: total esophagectomy; PE: partial esophagectomy; UK: unknown; HGIN: high grade intraepithelial neoplasia; LGIN: low grade intraepithelial neoplasia; TA: tubular adenoma; AC: adenocarcinoma; EMR: endoscopic mucosa resection; ESD: endoscopic submucosal dissection; SEMS: self-expanding metal stent. 
higher risk for colonic lesions such as adenoma and carcinoma $(4,50)$. In this context, the need for a structured endoscopic follow up must be highlighted. According to current international guidelines, follow-up colonoscopy for colorectal cancer screening is recommended 10 years after the first screening colonoscopy without pathologic findings (51). The risk of interval pathologies after colonic interposition, derived from included cohort studies, is extremely low. However, following the authors' personal opinion, follow up endoscopy should be applied within a closer interval, such as five years, even if preoperative colonoscopy was without pathologic findings and no risk factors were identified, as suggested by Imperiale and coworkers (52). Moreover, it has been previously shown before, that patients with adenocarcinoma of the esophagus have a significantly higher risk for the occurrence of colonic polyps (4). Because interval lesions are typical late complications and the risk increases over a longer time after index surgery, a life-long endoscopic follow-up must be postulated. In addition, the individual risk can be assessed by anamnestic factors such as colitis, history of colonic polyps, positive family history for colonic carcinoma (43). Positive information should lead to a closer follow-up interval. In addition, it is of significant importance to perform preoperative colonoscopy before using the colon as esophageal substitute.

\section{Limitations}

The presented systematic review is biased by the lack of randomized and structured prospective observational trials. None of the included cohort studies was rated with the full score of nine stars according to the Newcastle-Ottawa scale. This study is thereby at risk of being biased by the relatively low quality of these studies (e.g. lack of controls, short period of structured follow up, symptom-based follow-up). Data, extracted from case reports are all limited to the index case and give no information on the whole cohort. In this context, no risk calculation was possible.

\section{Authors' Recommendations}

The risk for pre-malignant and malignant interval pathologies within the colon interposition is extremely low. Therefore, the authors of the present review recommend:

- Preoperative assessment of the risk of development of colonic neoplasia;

- Standard preoperative colonoscopy;

- Lifelong endoscopic assessment of the interposed colon within an interval of five years;

- Adjustment of follow-up endoscopy to the individual's risk, preoperative endoscopic findings within the colon and potential interval pathologies.

\section{Conclusion}

In conclusion, esophageal substitute by parts of the colon is associated with a low but important risk of mucosal interval pathologies such as adenoma and carcinoma. This may be caused by the positional change of the colon as well as by individual risk factors. Therefore, preoperative endoscopic assessment of the colon must be strictly claimed, as well as a structured and life-long endoscopic follow up of the interposition. To date, no randomized trials or structured prospective observational studies are available on this topic. Overall, the available evidence is relevantly low, wherefore further investigations are of significant importance.

\section{Conflicts of Interest}

The Authors have no conflicts of interest to declare regarding this study.

\section{Authors' Contributions}

MS and PR designed the review, wrote the manuscript and analyzed results of literature research, AA revised the review and screened full text articles, ST did literature research and selected studies as well as data items, CM did literature research and selected studies as well as data items, FG did literature research and selected studies as well as data items, $\mathrm{AH}$ did native revision of the manuscript and designed the review together with MS and PR, JP revised the design and the manuscript, FA reviewed full text articles and selected data items. All Authors finally revised and approved the manuscript and agreed to be accountable for all aspects of the review.

\section{References}

1 Vuillet H: De l'oesophagoplastie et des diverses modifications. Semin Med 31: 529-534, 1911.

2 Kelling G: Oesophagoplastik mit Hilfe der Querkolon. Zentrabl Chir 38: 1209-1212, 1911.

3 DeMeester SR: Colon interposition following esophagectomy. Dis Esophagus 14(3-4): 169-172, 2001. PMID: 11869314. DOI: 10.1046/j.1442-2050.2001.00180.x

4 Bollschweiler E, Schloesser T, Leers J, Vallböhmer D, Schäfer $\mathrm{H}$ and Hölscher AH: High prevalence of colonic polyps in white males with esophageal adenocarcinoma. Dis Colon Rectum 52(2): 299-304, 2009. PMID: 19279427. DOI: 10.1007/ DCR.0b013e318197d06f

5 Shamseer L, Moher D, Clarke M, Ghersi D, Liberati A, Petticrew M, Shekelle P, Stewart LA; PRISMA-P Group: Preferred reporting items for systematic review and meta-analysis protocols (PRISMA-P) 2015: elaboration and explanation. BMJ 349: g7647, 2015. PMID: 25555855. DOI: 10.1136/bmj.g7647

6 Moher D, Liberati A, Tetzlaff $\mathrm{J}$ and Altman DG; PRISMA Group: Preferred reporting items for systematic reviews and meta-analyses: the PRISMA statement. PLoS Med 6(7): e1000097, 2009. PMID: 19621072. DOI: 10.1371/journal.pmed. 1000097 
7 Sohn M, Agha A, Trum E, Moser C, Iesalnieks I, Gundling F, Aigner F and Ritschl P: Frequency of metachronous polyps and adenocarcinoma in the interposed colon after esophagectomy in adults - protocol of a systematic review. Coloproctology 40(5): 349-351, 2018. DOI: 10.1007/s00053-018-0280-6

8 Evidence-Based Medicine Working Group: Evidence-based medicine. A new approach to teaching the practice of medicine. JAMA 268(17): 2420-2425, 1992. PMID: 1404801. DOI: 10.1001/jama.1992.03490170092032

9 Eriksen MB and Frandsen TF: The impact of patient, intervention, comparison, outcome (PICO) as a search strategy tool on literature search quality: a systematic review. J Med Libr Assoc JMLA 106(4): 420-431, 2018. PMID: 30271283. DOI: 10.5195/jmla.2018.345

10 Lo CK-L, Mertz D and Loeb M: Newcastle-Ottawa Scale: comparing reviewers' to authors' assessments. BMC Med Res Methodol 14: 45, 2014. PMID: 24690082. DOI: 10.1186/14712288-14-45

11 Akiyama $\mathrm{H}$ and Nakayama K: Carcinomas developing in the reconstructed esophagus. Int Adv Surg Oncol 5: 145-161, 1982. PMID: 7047405.

12 Eleftheriadis E, Dadoukis J, Kotzampassi K and Aletras H: Long-term results after esophagoplasty with colon. An endoscopic study. Int Surg 72(1): 11-12, 1987. PMID: 3596969.

13 Isolauri J, Helin $\mathrm{H}$ and Markkula $\mathrm{H}$ : Colon interposition for esophageal disease: histologic finding of colonic mucosa after a follow-up of 5 months to 15 years. Am J Gastroenterol 86(3): 277-280, 1991. PMID: 1998308.

14 Isolauri J: Colonic interposition for benign esophageal disease. Long-term clinical and endoscopic results. Am J Surg 155(3): 498-502, 1988. PMID: 3344918. DOI: 10.1016/s0002-9610(88) 80122-3

15 Pompeo E, Nofroni I, Van Raemdonck D, Coosemans W, Van Cleynenbreughel $\mathrm{B}$ and Lerut $\mathrm{T}$ : Esophagocoloplasty for congenital, benign and malignant diseases. Surgical and longterm functional results. Eur J Cardio-Thorac Surg 10(7): 561567, 1996. PMID: 8855430. DOI: 10.1016/s1010-7940(96) 80425-8.

16 Jeyasingham $\mathrm{K}$, Lerut $\mathrm{T}$ and Belsey RH: Functional and mechanical sequelae of colon interposition for benign oesophageal disease. Eur J Cardio-Thorac Surg 15(3): 327-332, 1999. PMID: 10333031. DOI: 10.1016/s1010-7940(99)00007-x

17 Szántó I, Kiss J, Vámosi-Nagy I and Vörös A: Endoscopic polypectomy in the segment of colon used for oesophageal replacement. Endoscopy 13(3): 134, 1981. PMID: 7238429. DOI: $10.1055 / \mathrm{s}-2007-1021667$

18 Kovacs BJ, Griffin RA and Chen YK: Synchronous adenomas in a colonic interposition graft and the native colon. Am J Gastroenterol 92(12): 2303-2304, 1997. PMID: 9399777.

19 Altomare JF and Komar MJ: A tubular adenoma arising in a colonic interposition. J Clin Gastroenterol 40(8): 765-766, 2006. PMID: 16940896. DOI: 10.1097/00004836-200609000-00022

20 Tanno N, Koyanagi K, Tabuchi S, Tawara H, Nishimura M, Togawa O, Arai S, Ishikawa K, Kita H, Nagata K and Koyama I: Lateral spreading tumor after esophagectomy and colon interposition. Prog Dig Endosc 77(2): 60-61, 2010. DOI: 10.11641/pde.77.2_60

21 Ramage L, Davies AR, Deguara J and Mason RC: Polyps arising in a colonic interposition graft: instigation of endoscopic graft surveillance may be required. Surgeon 10(5): 304-305, 2012. PMID: 22341002. DOI: 10.1016/j.surge.2011.11.001
$22 \mathrm{Ng}$ DWJ, Ching Tan GH and Teo MCC: Malignancy arising in a 41-year-old colonic interposition graft. Asian J Surg 39(1): 45-47, 2016. PMID: 24637188. DOI: 10.1016/j.asjsur. 2014.01.002

23 Goldsmith HS and Beattie EJ: Malignant villous tumor in a colon bypass. Ann Surg 167(1): 98-100, 1968. PMID: 5635190. DOI: 10.1097/00000658-196801000-00015

24 Licata AA, Fecanin P and Glowitz R: Metastatic adenocarcinoma from oesophageal colonic interposition. Lancet 1(8058): 285, 1978. PMID: 74716. DOI: 10.1016/s01406736(78)90543-3

25 Haerr RW, Higgins EM, Seymore $\mathrm{CH}$ and el-Mahdi AM: Adenocarcinoma arising in a colonic interposition following resection of squamous cell esophageal cancer. Cancer 60(9): 2304-2307, 1987. PMID: 3440237. DOI: 10.1002/10970142(19871101)60:9<2304:aid-cncr2820600931>3.0.co;2-x

26 Houghton AD, Jourdan M and McColl I: Dukes A carcinoma after colonic interposition for oesophageal stricture. Gut 30(6): 880-881, 1989. PMID: 2753412. DOI: 10.1136/gut.30.6.880

27 Theile DE, Smithers BM, Strong RW and Windsor CJ: Primary adenocarcinoma in a colonic oesophageal segment. Aust N Z J Surg 61(12): 953-955, 1991. PMID: 1755777. DOI: 10.1111/ j.1445-2197.1991.tb00015.x

28 Lee SJ, Koay CB, Thompson H, Nicolaides AR and Das Gupta AR: Adenocarcinoma arising in an oesophageal colonic interposition graft. J Laryngol Otol 108(1): 80-83, 1994. PMID: 8133180. DOI: $10.1017 /$ s0022215100125939

29 Altorjay A, Kiss J, Vörös A, Szanto I and Bohak A: Malignant tumor developed in colon-esophagus. Hepatogastroenterology 42(6): 797-799, 1995. PMID: 8847026.

30 Fritscher-Ravens A, Sriram PV, Thonke F, Jaeckle S, Maydeo A and Soehendra N: Synchronous adenocarcinoma in the transposed colonic conduit after esophagectomy for squamous cell cancer: endoscopic palliative resection while awaiting surgery. Gastrointest Endosc 50(6): 852-854, 1999. PMID: 10570353. DOI: 10.1016/s0016-5107(99)70175-6

31 Goyal M, Bang DH and Cohen LE: Adenocarcinoma arising in interposed colon: report of a case. Dis Colon Rectum 43(4): 555558, 2000. PMID: 10789758. DOI: 10.1007/bf02237206

32 Liau CT, Hsueh S and Yeow KM: Primary adenocarcinoma arising in esophageal colon interposition: report of a case. Hepatogastroenterology 51(57): 748-749, 2004. PMID: 15143907.

33 Hsieh YS, Huang KM, Chen TJ, Chou YH and OuYang CM: Metachronous adenocarcinoma occurring at an esophageal colon graft. J Formos Med Assoc 104(6): 436-440, 2005. PMID: 16037835.

34 Hwang HJ, Song KH, Youn YH, Kwon JE, Kim H, Chung JB and Lee YC: A case of more abundant and dysplastic adenomas in the interposed colon than in the native colon. Yonsei Med J 48(6): 1075-1078, 2007. PMID: 18159607. DOI: 10.3349/ ymj.2007.48.6.1075

35 Kuwabara Y, Kimura M, Mitsui A, Ishiguro H, Tomoda K, Mori Y, Ogawa R, Harata K, Katada T and Fujii Y: Adenocarcinoma arising in a colonic interposition following a total gastrectomy: report of a case. Surg Today 39(9): 800-802, 2009. PMID: 19779778. DOI: 10.1007/s00595-008-3932-2

36 Lin TC and Lin YC: Adenocarcinoma from esophageal colonic interposition. Chir Gastroenterol (24): 63-65, 2008. DOI: 10.1159/000109081 
37 Bando H, Ikematsu H, Fu KI, Oono Y, Kojima T, Minashi K, Yano T, Matsuda T, Saito Y, Kaneko K and Ohtsu A: A laterallyspreading tumor in a colonic interposition treated by endoscopic submucosal dissection. World J Gastroenterol 16(3): 392-394, 2010. PMID: 20082488. DOI: 10.3748/wjg.v16.i3.392

$38 \mathrm{Kia}$ L, Sikka SK and Komanduri S: An unusual case of malignant dysphagia after colonic interposition treated with endoscopic mucosal resection. Gastrointest Endosc 72(6): 13201321, 2010. PMID: 20554276. DOI: 10.1016/j.gie.2010.02.055

39 Shersher DD, Hong E, Warren W, Penfield Faber L and Liptay MJ: Adenocarcinoma in a 40-year-old colonic interposition treated with Ivor Lewis esophagectomy and esophagogastric anastomosis. Ann Thorac Surg 92(6): e113-114, 2011. PMID: 22115265. DOI: 10.1016/j.athoracsur.2011.06.025

40 Kim ES, Park KS, Cho KB and Kim MJ: Adenocarcinoma occurring at the interposed colon graft for treatment of benign esophageal stricture. Dis Esophagus 25(2): 175, 2012. PMID: 20459445. DOI: 10.1111/j.1442-2050.2010.01056.x

41 Spitali C, De Vogelaere K and Delvaux G: Dysphagia after colon interposition graft for esophageal carcinoma. Case Rep Pathol 738205, 2012. PMID: 23198233. DOI: 10.1155/2012/738205

42 Sikorszki L, Horváth OP, Papp A, Cseke L and Pavlovics G: Colon cancer after colon interposition for oesophageal replacement. Magy Sebeszet 63(4): 157-160, 2010. PMID: 20724239. DOI: 10.1556/MaSeb.63.2010.4.2

43 Aryal MR, Mainali NR, Jalota L and Altomare JF: Advanced adenocarcinoma in a colonic interposition segment. BMJ Case Rep, 2013. PMID: 23687370. DOI: 10.1136/bcr-2013-009749

44 Grunner S, Gilshtein H, Kakiashvili E and Kluger Y: Adenocarcinoma in colonic interposition. Case Rep Oncol 6(1): 186-188, 2013. PMID: 23626559. DOI: 10.1159/000350743

45 Tranchart H, Chirica M, Munoz-Bongrand N, Sarfati E and Cattan P: Adenocarcinoma on colon interposition for corrosive esophageal injury: case report and review of literature. J Gastrointest Cancer 45: 205-207, 2014. PMID: 24943871. DOI: 10.1007/s12029-014-9629-4

46 Cheng YC, Wu CC, Lee CC, Hsiao CW, Lee TY, Jao SW and Ho CL: Adenocarcinoma of a colonic interposition graft for benign esophageal stricture in a young woman. Endoscopy 47 UCTN: E249-250, 2015. PMID: 26099075. DOI: 10.1055/s0034-1377377
47 Kröner PT and Mönkemüller K: Dual esophageal and colon selfexpanding metal stenting for colon cancer arising in esophageal interposition. Endoscopy 47 UCTN: E221-222, 2015. PMID: 26062158. DOI: $10.1055 / \mathrm{s}-0034-1391830$

48 Greene CL, DeMeester SR, Augustin F, Worrell SG, Oh DS, Hagen JA and DeMeester TR: Long-term quality of life and alimentary satisfaction after esophagectomy with colon interposition. Ann Thorac Surg 98(5): 1713-1720, 2014. PMID: 25258155. DOI: 10.1016/j.athoracsur.2014.06.088

49 Hwang HJ, Song KH, Youn YH, Kwon JE, Kim H, Chung JB and Lee YC: A case of more abundant and dysplastic adenomas in the interposed colon than in the native colon. Yonsei Med J 48(6): 1075-1078, 2007. PMID: 18159607. DOI: 10.3349/ ymj.2007.48.6.1075

50 Miyazaki T, Tanaka N, Sano A, Suzuki S, Sakai M, Yokobori T, Inose T, Sohda M, Nakajima M, Fukuchi M, Ojima H, Kato H and Kuwano H: Clinical significance of total colonoscopy for screening of colon lesions in patients with esophageal cancer. Anticancer Res 33(11): 5113-5117, 2013. PMID: 24222157.

51 S3-Leitlinie Kolorektales Karzinom, Langversion 2.0, 2017, AWMF Registrierungsnummer: 021/007OL. Available at: http:// www.leitlinienprogramm-onkologie.de/leitlinien/kolorektaleskarzinom/

52 Imperiale TF, Glowinski EA, Lin-Cooper C, Larkin GN, Rogge JD and Ransohoff DF: Five-year risk of colorectal neoplasia after negative screening colonoscopy. N Engl J Med 359(12): 1218-1224, 2008. PMID: 18799558. DOI: 10.1056/NEJM oa0803597 